\title{
Impact of air-abrasion on fracture load and failure type of veneered anterior Y-TZP crowns before and after chewing simulation
}

\author{
Stawarczyk, Bogna ; Özcan, Mutlu ; Hallmann, Lubica ; Roos, Malgorzata ; Trottmann, Albert ; Hämmerle,
} Christoph H F

\begin{abstract}
The purpose of this study was to determine the fracture load and failure types of veneered zirconia crowns that were air-abraded on either the veneering or cementation surface. Fracture loads were determined before and after chewing simulation. Standardized Y-TZP frameworks $(n=360)$ for canines were fabricated and divided into one control group $(n=72)$ and 12 test groups $(n=24)$. The test groups were air-abraded using alumina powder $(10 \mathrm{~s}, 2 \mathrm{bar}$, distance: $10 \mathrm{~mm})$ with particle size of $50 \mu \mathrm{m}$ resp. $110 \mu \mathrm{m}$ and veneered with one of the veneering ceramics: Triceram, Zirox, or VITA VM9. The crowns were cemented on their corresponding CoCr abutment. The initial fracture load was measured in one half of each group $(n=12)$, and the other half $(n=$ 12) was subjected to chewing cycling. The data were analyzed using three-way and one-way ANOVA, a post-hoc Scheffé test, two sample Student's t-test, and Weibull statistics $(\mathrm{p}<0.05)$. Thus, nonaged, air-abraded groups of two veneering ceramics (Triceram, VITA VM9) showed higher mean fracture load compared to control groups. After chewing simulation, air-abraded groups showed lower mean fracture load compared to control groups. Aging decreased the Weibull modulus of all tested groups, and air-abraded groups showed lower Weibull moduli compared to control groups.
\end{abstract}

DOI: https://doi.org/10.1002/jbm.b.32737

Posted at the Zurich Open Repository and Archive, University of Zurich

ZORA URL: https://doi.org/10.5167/uzh-64939

Journal Article

Accepted Version

Originally published at:

Stawarczyk, Bogna; Özcan, Mutlu; Hallmann, Lubica; Roos, Malgorzata; Trottmann, Albert; Hämmerle, Christoph H F (2012). Impact of air-abrasion on fracture load and failure type of veneered anterior Y-TZP crowns before and after chewing simulation. Journal of Biomedical Materials Research. Part B: Applied Biomaterials, 100(6):16831690.

DOI: https://doi.org/10.1002/jbm.b.32737 


\section{Journal: J Biomed Mater Res B Appl Biomater}

Impact of air-abrasion on fracture load and failure type of veneered anterior $\mathrm{Y}$ TZP crowns before and after chewing simulation

Short title: Impact of air-abrasion on fracture load of zirconia crowns

Bogna Stawarczyk ${ }^{1}$, Mutlu Özcan ${ }^{1}$, Lubica Hallmann ${ }^{1}$, Malgorzata Roos ${ }^{2}$, Albert Trottmann ${ }^{1}$, Christoph H. F. Hämmerle ${ }^{1}$

${ }^{1}$ Clinic of Fixed and Removable Prosthodontics and Dental Material Science, Center of Dental Medicine, University of Zurich, Switzerland

${ }^{2}$ Division of Biostatistics, Institute of Social and Preventive Medicine, University of Zurich, Switzerland

Corresponding author: Dipl. Ing. Bogna Stawarczyk, MSc

Plattenstrasse 11, 8032 Zurich, Switzerland

bogna.stawarczyk@zzm.uzh.ch

Tel. $\quad+41446343365$

Fax $\quad+41446344305$ 


\section{Abstract:}

The purpose of this study was to determine the fracture load and failure types of veneered zirconia crowns that were air-abraded on either the veneering or cementation surface. Fracture loads were determined before and after chewing simulation. Standardized Y-TZP frameworks $(\mathrm{N}=360)$ for canines were fabricated. Seventy-two non-conditioned frameworks acted as control. The remaining frameworks $(n=288)$ were randomly divided into four groups $(n=72)$ and air-abraded using alumina powder for $10 \mathrm{~s}$ at a pressure of $2 \mathrm{bar}$ and a distance of $10 \mathrm{~mm}$ with one of the following procedures: i) cementation surface of zirconia crown with particle size of $50 \mu \mathrm{m}$, ii) cementation surface of zirconia crown with particle size of $110 \mu \mathrm{m}$, iii) veneering surface of zirconia crown with particle size of $50 \mu \mathrm{m}$ and iv) veneering surface of zirconia crown with particle size of $110 \mu \mathrm{m}$. Each group was then randomly divided into three subgroups $(n=24)$ and veneered with one of the veneering ceramic: Triceram, Zirox or VITA VM9. The crowns were cemented on their corresponding CoCr abutment. The initial fracture load was measured in one half of each group $(n=12)$ and the other half $(n=12)$ was subjected to chewing cycling (1.2 Mio, $49 \mathrm{~N}$, $\left.5^{\circ} \mathrm{C} / 50^{\circ} \mathrm{C}\right)$. The data were analysed using 3-way and 1-way ANOVA, followed by a post-hoc Scheffé test, two sample Student's t-test and Weibull statistics $(p<0.05)$. Among non-aged groups, air-abraded zirconia crowns $(110 \mu \mathrm{m})$ either on the cementation or veneering surface, subsequently veneered using Triceram (cementation surface: $1317 \mathrm{~N}$, veneering surface: $1317 \mathrm{~N}$ ) and VITA VM9 (cementation surface: $1435 \mathrm{~N}$, veneering surface: 1296) showed significantly higher fracture load compared to control groups (Triceram: 1093 N, VITA VM9: 1089). After chewing simulation within one veneering ceramic (Triceram), cementation surface with $110 \mu \mathrm{m}$ air-abraded $(780 \mathrm{~N})$ showed significantly lower values compared to 50 
$\mu \mathrm{m}$ air-abraded (966 N) and control group (1076 N). All aged, veneering surface airabraded (50 and $110 \mu \mathrm{m})$ groups (637-966 N) showed significantly lower values than the control groups (963-1076 N). Non-aged groups (4.5-10.4) showed higher Weibull moduli compared to aged groups (3.8-9.2). For aged control groups (5.8-7.4) higher Weibull moduli were observed than for aged air-abraded groups (3.8-7.2). Airabrasion of zirconia cementation and veneering surfaces of single crowns at 2 bar with $50 \mu \mathrm{m}$ and $110 \mu \mathrm{m}$ decreased fracture load after chewing simulation.

Gekürztes Abstract (exakt 200 Wörter... (:)

The purpose of this study was to determine the fracture load and failure types of veneered zirconia crowns that were air-abraded on either the veneering or cementation surface. Fracture loads were determined before and after chewing simulation. Standardized Y-TZP frameworks $(\mathrm{N}=360)$ for canines were fabricated and divided into 1 control group $(n=72)$ and 12 test groups $(n=24)$. The test groups were air-abraded using alumina powder (10s, 2 bar, distance: $10 \mathrm{~mm}$ ) with particle size of $50 \mu \mathrm{m}$ resp. $110 \mu \mathrm{m}$ and veneered with one of the veneering ceramics: Triceram, Zirox or VITA VM9. The crowns were cemented on their corresponding $\mathrm{CoCr}$ abutment. The initial fracture load was measured in one half of each group $(n=12)$ and the other half $(n=12)$ was subjected to chewing cycling. The data were analysed using 3-way and 1-way ANOVA, a post-hoc Scheffé test, two sample Student's t-test and Weibull statistics $(\mathrm{p}<0.05)$. Thus, non-aged, air-abraded groups of two veneering ceramics (Triceram, VITA VM9) showed higher mean fracture load compared to control groups. After chewing simulation, air-abraded groups showed lower mean fracture load compared to control groups. Aging decreased the Weibull modulus of all 
tested groups and air-abraded groups showed lower Weibull moduli compared to control groups.

Keywords: veneered ceramic, zirconia, all-ceramic, air-abrasion, fracture load, failure types, chewing simulation 


\section{INTRODUCTION}

Y-TZP frameworks could be processed due to the advances in dental CAD/CAM technology. Thus, all ceramic fixed dental prostheses (FDP) are feasible, since high flexural strength and fracture toughness of Y-TZP allows application of framework materials for the posterior region. ${ }^{1,2}$ The excellent mechanical properties are due to the finer grain size and the tetragonal-monoclinic transformation toughening mechanism of the zirconia, which leads to higher compressive stresses in the material and results in reduced crack propagation. ${ }^{3-5}$

Limited number of clinical studies reported seldom zirconia framework fractures but more often chipping of the veneering ceramic. ${ }^{6-10}$ In-vitro studies reported, that bonding between veneering ceramics and zirconia might be based on chemical bonds. ${ }^{11-13}$ According to previous studies, whether the zirconia surface is air-abraded or polished did not affect bond strength. ${ }^{11-13}$ Failure of the veneer in these studies occurred close to the zirconia/veneer interface with residual veneering ceramic remaining on the zirconia. ${ }^{11,12}$ However, air-abrasion also causes a phase transition of zirconia from the tetragonal to the monoclinic crystal structure ${ }^{14,15}$ which might thereby probably affect the bond quality. Therefore, the effect of air-abrasion on the mechanical strength of Y-TZP and the bond quality to veneering ceramics is currently controversially discussed. ${ }^{14,16,17}$

In contrast to bond strength of veneering ceramic to zirconia, many studies reported lower bond strength values of untreated zirconia to resin cements. ${ }^{18}$ Studies reported that the long-term durability of the resin bond to zirconia is indispensable for many applications and can be obtained with various methods when using airabrasion. ${ }^{18-25}$ Furthermore the bond strength may depend on other parameters as well, such as the strength of the chemical bonds, the mechanical interlocking, the 
type and concentration of defects at the interface and wetting properties of the adhesives and the resin cements. ${ }^{26-28} \ldots \ldots$...Air-abrasion of the zirconia surface is expected to increase the bond quality between resin cement and zirconia. ${ }^{18-22,25}$

Air-abrasion with alumina powder is commonly used to clean the surface and achieve both micro-retentive topography and increased surface area. ${ }^{29}$ It results in a highly activated surface that can be shown by the increased wettability of the material. ${ }^{29}$ Therefore, many manufacturers recommend air-abrasion of zirconia frameworks before veneering process.

The stability of the complete system, consisting of the Y-TZP framework and the veneering ceramic, is of clinical importance and can be tested with the Vosstest. $^{30}$ In this test, the anatomy of the crowns is not excluded and can therefore represent the clinical conditions better compared to standard tests where geometrical specimens with standard dimensions are used. The restoration is cemented on the metal abutments and force is applied to the crowns simulating the antagonist load. The Voss-test was originally developed to test the fracture load of metal-ceramic FDPs $^{30}$ but it is also being applied for zirconia FDPs. ${ }^{2,31-33}$

Since available studies show very diverse conclusions about air-abrasion, ${ }^{11-13,}$ 18-25 the aim of this study was to determine the fracture load and failure types of veneered zirconia crowns that were air-abraded on either the veneering or cementation surface. Fracture loads were determined before and after chewing simulation. The tested hypothesis was whether cementation and veneering surface air-abraded and subsequently veneered zirconia crowns show similar fracture load compared to control groups before and after aging. 


\section{MATERIALS AND METHODS}

\section{Specimens preparation}

A standard metal abutment ${ }^{33}$ was scanned (3Shape D 250, Wieland Dental) and an anatomically supported Y-TZP framework was constructed (ZENO TEC Wieland Dental), milled (ZENO 4030 M1, Wieland Dental) and sintered using a predefined firing schedule (ZENO TEC Fire, Wieland Dental). Seventy-two frameworks out of the total of 360 were not conditioned. The remaining frameworks $(n=288)$ were randomly divided into four groups $(n=72)$ and air-abraded:

(A) Air-abrasion of cementation surface with alumina powder with a mean particle size of $50 \mu \mathrm{m}$ (LEMAT NT4, Wassermann, Hamburg, Germany) for $10 \mathrm{~s}$ at a pressure of 2 bar and at a distance of $10 \mathrm{~mm}$ between the nozzle and the zirconia surface

(B) Air-abrasion of cementation surface with alumina powder with a mean particle size of $110 \mu \mathrm{m}$ as described under point $(\mathrm{A})$

(C) Air-abrasion of veneering surface with alumina powder with a mean particle size of $50 \mu \mathrm{m}$ (LEMAT NT4, Wassermann, Hamburg, Germany) for $10 \mathrm{~s}$ at a pressure of 2 bar and at a distance of $10 \mathrm{~mm}$ between the nozzle and the zirconia surface

(D)Air-abrasion of veneering surface with alumina powder with a mean particle size of $110 \mu \mathrm{m}$ as described under point (C)

Subsequently, the control group and the 4 air-abraded groups were randomly divided into three subgroups each $(n=24)$ and veneered with one of the veneering ceramic: Triceram (Dentaurum, Ispringen, Germany), Zirox (Wieland + Dental, Pforzheim, Germany) or VITA VM9 (Vita Zahnfabrik, Bad Säckingen, Germany) (Table 1). Veneering ceramic for dentin was applied using a silicone key to achieve 
standardized shape and size of the layered veneers. In a second firing, dentin was added to compensate for the shrinkage of the sintering process. Prior to the second firing, the slurry was condensed into the mould using a vibrator for $2 \mathrm{~s}$ at $50 \mathrm{~Hz}$ (Elektro Vibrator Porex, Renfert, Hilzingen, Germany). The veneered crowns were cemented with glass ionomer cement (KetacCem, 3M ESPE, Seefeld, Germany) to their corresponding $\mathrm{CoCr}$ abutment analog according to the manufacturer's instruction.

\section{Specimens aging}

The initial fracture load was measured in one half of each group $(n=12)$ and the other half $(n=12)$ was subjected to chewing cycling (custom made device at the University of Zurich). The crowns were mechanically loaded with $49 \mathrm{~N}$ for 1.2 million times at the frequency of $1.7 \mathrm{~Hz}$. Simultaneous thermocycling was applied by changing the surrounding water temperature from $5^{\circ} \mathrm{C}$ to $50^{\circ} \mathrm{C}$ every $120 \mathrm{~s}$. In total, the temperature changed 6.000 times during the occlusal loading. ${ }^{34}$ Flat polished composite antagonists (Tetric EvoCeram, Ivoclar Vivadent, Schaan, Liechtenstein) were used.

\section{Fracture load measurement}

To measure fracture load the specimens were loaded in a Universal Testing Machine (1 mm/min; Zwick/Roell Z010, Zwick, Ulm, Germany). The load was induced with a flat jig on the palatal surface of the incisal edge at an angle of 45 degrees to the long axis of the tooth. $^{32,33}$ To achieve even force distribution, a $0.5 \mathrm{~mm}$ tin foil (Dentaurum, Ispringen, Germany) was placed between the incisal edge and the loading jig. The fracture load was registered as soon as the fracture load decreased by $10 \%$ of the maximum load (Fmax). 


\section{Failure types analysis}

The failure types were observed by two operators under an optical microscope (M3M, Wild, Heerbrugg, Switzerland) (x25) and categorized as follows: a) chipping of the veneering ceramic or b) fracture of the veneering ceramic together with total fracture of the framework.

For the qualitative characterisation of the air-abraded surface, the specimens were evaluated under scanning electron microscopy (SEM) (Carl Zeiss Supra 50 VP FESEM, Carl Zeiss, Oberkochen, Germany). Specimens were gold sputtered and SEM was operated at $5 \mathrm{kV}$ and with a working distance of 6.5-7.0 mm.

\section{Statistical analysis}

The fracture load data were analyzed with 3-way and 1-way ANOVA, followed by a post hoc Scheffé test, and two sample Student's t-test based on the assumption of normal data distribution. In addition, the parameters of the Weibull distribution (Weibull modulus and the characteristic fracture load) were estimated by Maximum Likelihood and $95 \% \mathrm{Cl}$ was computed. The Statistical Package for the Social Science Version 19 (SPSS INC, Chicago, IL, USA) for normal distribution and MINITAB Version 14 (MINITAB, State College, PA, USA) for Weibull distribution were used $(p<0.05)$. Failure types were classified as either chipping or total fracture. The relative frequencies were computed together with the corresponding $95 \% \mathrm{Cl}^{35}$ 


\section{RESULTS}

Descriptive statistics (mean, SD, $95 \% \mathrm{Cl}$ ) of the measured fracture load of each airabraded group is presented in Table II. The veneering ceramic $(p=0.001)$, airabrasion $(p<0.001)$ and aging $(p<0.001)$ had a significant effect on the fracture load results. The interaction terms were also significant $(p<0.001)$.

\section{Impact of veneering ceramic}

Within the groups that were air-abraded $(110 \mu \mathrm{m})$ on the cementation surface, Vita VM9 showed a statistically higher initial fracture load compared to Zirox $(p=0.043)$. No further statistical differences were found between the veneering ceramic within the conditioning and within the aging levels $(p=0.054-0.947)$ (Table II).

\section{Impact of air-abrasion of cementation surface before and after aging}

Within veneering ceramic Triceram, air-abraded $(110 \mu \mathrm{m})$ crowns showed higher initial fracture load compared to control group $(p=0.034)$. Among the veneering ceramic Vita VM9, air-abraded groups $(50 \mu \mathrm{m}$ and $110 \mu \mathrm{m})$ presented higher initial fracture load than the control group $(p<0.001)$. No impact of air-abrasion on the initial fracture load was observed for Zirox groups $(p=0.137)$ (Table II, Fig. 1).

Within veneering ceramic Triceram, after chewing simulation the groups airabraded on the cementation surface with $110 \mu \mathrm{m}$ showed significantly lower fracture load than the control group and the groups air-abraded with $50 \mu \mathrm{m}(p=0.001)$. No impact of air-abrasion was found for Zirox and Vita VM9 after chewing simulation $(p=0.169-0.37)$ (Table II, Fig. 2).

Impact of air-abrasion of veneering surface before and after aging 
Within veneering ceramics Triceram $(p=0.017)$ and VITA VM9 $(p=0.042)$, air-abraded $(110 \mu \mathrm{m})$ veneering surface showed significantly higher results compared to control group. In groups veneered with Zirox no differences were found $(p=0.227)$ (Table II, Fig. 1).

After chewing simulation, all air-abraded groups with $110 \mu \mathrm{m}$ showed significantly lower fracture load compared to control groups with the same veneering ceramic $(p<0.001-p=0.022)$. Additionally, Triceram decreased mean fracture load after air-abrasion with $50 \mu \mathrm{m}$ alumina powder $(p=0.001)$ (Table II, Fig. 2).

Impact of air-abrasion side (cementation surface vs. veneering surface)

Within the non-aged groups no statistically differences were observed when airabrasion was performed either on the cementation or veneering surface $(p>0.05)$. In aged Zirox crowns, veneering surface air-abraded $(110 \mu \mathrm{m})$ showed significantly lower facture load than those air-abraded $(110 \mu \mathrm{m})$ on the cementation surface crowns $(p=0.004)$. All other groups presented no significant impact of air-abrasion surface (veneering or cementation) on the fracture load results $(p>0.05)$.

\section{Impact of aging}

The mean fracture load of control groups within each veneering ceramic showed no significant influence of aging $(p>0.05)$. Among Triceram $(p=0.001-0.017)$ and VITA VM9 $(p=0.001-0.022)$ air-abraded $(50 \mu \mathrm{m}$ and $110 \mu \mathrm{m})$ groups, the fracture load significantly decreased after chewing simulation. Air-abraded $(110 \mu \mathrm{m})$ and aged Zirox groups showed significantly lower values compared to non-aged ones $(p=0.001-0.003)$.

Weibull statistics 
Non-aged groups (4.5-10.4) showed higher Weibull moduli compared to aged ones (3.8-9.2). For aged control groups (5.8-7.4) higher Weibull moduli was calculated than for air-abraded aged groups (3.8-7.2) (Table III).

Failure types

In the control group framework total fracture was observed $16.7-50 \%$ in non-aged conditions and 33.3-58.3\% after aging. $50 \mu \mathrm{m}$ air-abraded groups showed $25-66.7 \%$ total fracture in non-aged conditions and $50-100 \%$ after aging. On the other hand, in non-aged conditions $110 \mu \mathrm{m}$ air-abraded groups showed $25-66.7 \%$ total fracture and after aging $58.3-100 \%$ (Table IV).

Chipping?

Qualitative characterization of the air-abraded zirconia surfaces under SEM

The qualitative characterization of the air-abraded zirconia surfaces using alumina powder with a mean particle size of $50 \mu \mathrm{m}$ and $110 \mu \mathrm{m}$ for $10 \mathrm{~s}$ at a pressure of 2 bar and a distance of $10 \mathrm{~mm}$ showed damage on the surface in the form of micro cracks (Fig. 3).

Oder:

The qualitative characterization of the air-abraded zirconia showed damage on the surface in the form of micro cracks when using alumina powder with a mean particle size of $50 \mu \mathrm{m}$ and $110 \mu \mathrm{m}$ for $10 \mathrm{~s}$ at a pressure of $2 \mathrm{bar}$ and a distance of $10 \mathrm{~mm}$ (Fig 3). 


\section{DISCUSSIONS}

This study demonstrated that the initial fracture load of air-abraded and then veneered Y-TZP crowns showed higher values compared to non treated FDPs. Based on the present results, the null-hypothesis that the air-abrasion of Y-TZP crowns has no impact on fracture load could be rejected. One early study reported that air-abrasion prior to veneering and cementation decrease the fracture strength of zirconia. ${ }^{36}$ Resin cement bond strength to zirconia is still not sufficient therefore other pre-treatment methods than air-abrasion such as silanization are necessary in the future.

In this study, the fracture load after chewing simulation showed significantly lower values for air-abraded FDPs compared to non-treated zirconia crowns. In addition, the Weibull moduli after chewing simulation for air-abraded crowns decreased. The SEM picture of air-abraded (50 and $110 \mu \mathrm{m})$ Y-TZP surfaces showed damage on the surface in the form of micro cracks supporting one possible reason for decreased fracture load. The air-abrasion process could be responsible for the damage of the zirconia surface, which negatively influences the mechanical properties and reliability of zirconia. ${ }^{32,37}$ These areas of surface flaws act as stress concentration sites and even though their size is microscopic in nature, they act as potential sites for crack initiation and propagation. ${ }^{38,39}$ In this study, the failure analysis for air-abraded groups showed predominantly framework fracture after chewing simulation. The tested specimens were abraded using alumina powder with a mean particle size of 50 or $110 \mu \mathrm{m}$ for $10 \mathrm{~s}$ at a pressure of $2 \mathrm{bar}$ and a distance of $10 \mathrm{~mm}$. Further studies should determine the fracture load of air-abraded zirconia FDPs using other air-abrasion parameters with lower pressure. 
In this study, three different veneer ceramics for veneering of zirconia frameworks were used with different glass transition temperature (Tg) (Triceram: 558 ${ }^{\circ} \mathrm{C}$, Zirox: $576{ }^{\circ} \mathrm{C}$ and VITA VM9: $\left.604^{\circ} \mathrm{C}\right)^{40}$ and different coefficients of thermal expansion (Triceram: $8.7 \times 10^{-6} / \mathrm{K}$, VITA VM9: $9.3 \times 10^{-6} / \mathrm{K}$ and Zirox: $\left.9.8 \times 10^{-6} / \mathrm{K}\right)^{40}$ tested between $25^{\circ} \mathrm{C}$ and $500^{\circ} \mathrm{C}$. Previous study obtained a correlation between fracture load of veneered zirconia crowns and $\mathrm{Tg}$ and coefficients of thermal expansion where no air-abrasion was practiced. ${ }^{31}$ In this study no clear correlation between fracture load and glass transition temperature and coefficient of thermal expansion could be found.

The crucial point is the internal tensile stresses in the veneering ceramic affecting the fracture type such as chipping. Tensile stresses could occur through several mechanisms and it is possible that a phase transformation took place during the air-abrasion of zirconia framework, resulting in an additional monoclinical phase. The coefficient of thermal expansion of monoclinic zirconia $\left(7.5 \times 10^{-6} / \mathrm{K}\right)^{41}$ is significantly lower than the one of tetragonal zirconia $\left(10.8 \times 10^{-6} / \mathrm{K}\right){ }^{2}$

The test method used according to Voss induces tensile forces from the outer crown surface until the crown fails and thereby determine fracture load. This facture load represents the internal tensile stresses within the crown after firing as well as the bond and flexural strength of the framework together with the veneering ceramic.

The internal tensile stresses built up in the crown can be influenced by differences in the coefficient of thermal expansion between zirconia framework and veneering ceramic ${ }^{31}$, in the dimension and anatomical support of the crown and the veneering ceramic, in the thickness, ${ }^{42}$ and in the glass transition temperature of the veneering ceramic ${ }^{31}$. As a consequence of the applied load in combination with the internal compression, the crown eventually fractures. In clinical studies, fractures of 
zirconia framework are rarely reported ${ }^{6-10}$, because the chewing forces in the mouth seem not to exceed their mean fracture load. Failure types observed in this study do not correlate with the clinical failure patterns. In this respect, the results derived from static loading tests can be considered as extreme values that possibly do not occur in the oral environment. Hence, it can be stated that the values obtained in such tests are far above the natural chewing forces. 


\section{CONCLUSIONS}

Within the limitations of this in-vitro study it can be concluded that:

1. Non-aged, air-abraded groups of two veneering ceramics showed higher mean fracture load compared to control groups.

2. After chewing simulation, air-abraded groups showed lower mean fracture load compared to control groups.

3. Aging decreased the Weibull moduli of all tested groups. Air-abraded groups showed lower Weibull moduli compared to control groups.

4. SEM-images showed damage in the form of micro cracks on the air-abraded zirconia surface.

\section{Acknowledgments}

The authors would like to thank Dentaurum, Wieland Dental and Vita Zahnfabrik for their support with the materials and to Dirk Jahn (nt-trading, Neustadt an der Weinstrasse, Germany) for fabricating all zirconia frameworks. 


\section{References}

1. Luthy H, Filser F, Loeffel O, Schumacher M, Gauckler LJ, Hammerle $\mathrm{CH}$. Strength and reliability of four-unit all-ceramic posterior bridges. Dent Mater 2005;21:930-937.

2. Fischer J, Stawarczyk B. Compatibility of machined Ce-TZP/AI2O3 nanocomposite and a veneering ceramic. Dent Mater 2007;23:1500-1505.

3. Kelly JR, Denry I. Stabilized zirconia as a structural ceramic: an overview. Dent Mater 2008;24:289-298.

4. Hannink R, Kelly P, BC M. Transformation toughening in zirconia-containing ceramics. J Am Ceram Soc 2000;83:461-487.

5. Steffen A, Dauskardt R, Ritchie R. Cyclic fatique-life and crack-growth behavior of microstructurally small cracks in magnesia-partially stabilized zirconia ceramics. J Am Ceram Soc 1991;74:1259-1268.

6. Vult von Steyern P, Carlson P, Nilner K. All-ceramic fixed partial dentures designed according to the DC-Zirkon technique. A 2-year clinical study. J Oral Rehabil 2005;32:180-187.

7. Raigrodski AJ, Chiche GJ, Potiket N, Hochstedler JL, Mohamed SE, Billiot S, et al. The efficacy of posterior three-unit zirconium-oxide-based ceramic fixed partial dental prostheses: a prospective clinical pilot study. J Prosthet Dent 2006;96:237-244.

8. Sailer I, Feher A, Filser F, Gauckler LJ, Luthy H, Hammerle CH. Five-year clinical results of zirconia frameworks for posterior fixed partial dentures. Int $J$ Prosthodont 2007;20:383-388.

9. Edelhoff D, Florian B, Florian W, Johnen C. HIP zirconia fixed partial dentures-clinical results after 3 years of clinical service. Quintessence Int 2008;39:459471.

10. Schmitt J, Holst S, Wichmann M, Reich S, Gollner M, Hamel J. Zirconia posterior fixed partial dentures: a prospective clinical 3-year follow-up. Int J Prosthodont 2009;22:597-603.

11. Fischer J, Grohmann P, Stawarczyk B. Effect of zirconia surface treatments on the shear strength of zirconia/veneering ceramic composites. Dent Mater $\mathrm{J}$ 2008;27:448-454.

12. Fischer J, Stawarczyk B, Sailer I, Hammerle $\mathrm{CH}$. Shear bond strength between veneering ceramics and ceria-stabilized zirconia/alumina. The $\mathrm{J}$ Prosthet Dent 2010;103:267-274.

13. Aboushelib MN, de Jager N, Kleverlaan CJ, Feilzer AJ. Microtensile bond strength of different components of core veneered all-ceramic restorations. Dent Mater 2005;21:984-991.

14. Kosmac T, Oblak C, Jevnikar P, Funduk N, Marion L. The effect of surface grinding and sandblasting on flexural strength and reliability of Y-TZP zirconia ceramic. Dent Mater 1999;15:426-433.

15. Guazzato M, Albakry M, Quach L, Swain MV. Influence of surface and heat treatments on the flexural strength of a glass-infiltrated alumina/zirconiareinforced dental ceramic. Dent Mater 2005;21:454-463.

16. Kosmac T, Oblak C, Jevnikar P, Funduk N, Marion L. Strength and reliability of surface treated Y-TZP dental ceramics. J Biomed Mater Res 2000;53:304313.

17. Zhang $Y$, Lawn BR, Malament KA, Van Thompson P, Rekow ED. Damage accumulation and fatigue life of particle-abraded ceramics. Int J Prosthodont 2006;19:442-448. 
18. Kern M, Wegner SM. Bonding to zirconia ceramic: adhesion methods and their durability. Dent Mater 1998;14:64-71.

19. Shahin R, Kern M. Effect of air-abrasion on the retention of zirconia ceramic crowns luted with different cements before and after artificial aging. Dent Mater 2010;26:922-928.

20. Blatz MB, Sadan A, Kern M. Ceramic restorations. Compendium of Continuing Education in Dentistry 2004;25:412, 14, 16 passim.

21. Hummel $M$, Kern $M$. Durability of the resin bond strength to the alumina ceramic Procera. Dent Mater 2004;20:498-508.

22. Wegner SM, Gerdes W, Kern M. Effect of different artificial aging conditions on ceramic-composite bond strength. Int J Prosthodont 2002;15:267-272.

23. Wegner SM, Kern M. Long-term resin bond strength to zirconia ceramic. J Adhes Dent 2000;2:139-147.

24. Blatz MB, Sadan A, Soignet D, Blatz U, Mercante D, Chiche G. Long-term resin bond to densely sintered aluminum oxide ceramic. J Esthet Restor Dent 2003;15:362-368; discussion 69.

25. Ozcan M, Vallittu PK. Effect of surface conditioning methods on the bond strength of luting cement to ceramics. Dent Mater 2003;19:725-731.

26. al-Shehri SA, Mohammed $\mathrm{H}$, Wilson CA. Influence of lamination on the flexural strength of a dental castable glass ceramic. J Prosthet Dent 1996;76:23-28.

27. Isgro G, Pallav P, van der Zel JM, Feilzer AJ. The influence of the veneering porcelain and different surface treatments on the biaxial flexural strength of a heat-pressed ceramic. J Prosthet Dent 2003;90:465-473.

28. De Jager N, Pallav P, Feilzer AJ. Finite element analysis model to simulate the behavior of luting cements during setting. Dent Mater 2005;21:1025-1032.

29. Kern M, Thompson VP. Effects of sandblasting and silica-coating procedures on pure titanium. J Dent 1994;22:300-306.

30. Voss R. Stability of metal-ceramic crowns (die Festigkeit metallkeramischer Kronen). Deutsch Zahnärztl Zeitschrift 1969;24:726-31.

31. Fischer J, Stawarczyk B, Trottmann A, Hammerle $\mathrm{CH}$. Impact of thermal properties of veneering ceramics on the fracture load of layered Ce-TZP/A nanocomposite frameworks. Dent Mater 2009;25:326-330.

32. Stawarczyk B, Ozcan M, Roos M, Trottmann A, Hammerle CH. Fracture load and failure analysis of zirconia single crowns veneered withpressed and layered ceramics after chewing simulation. Dent Mater J 2011;30:554-562.

33. Stawarczyk B, Özcan M, Roos M, Trottmann A, Sailer I, Hämmerle CHF. Load-bearing capacity and failure types of anterior zirconia crowns veneered with overpressing and layering techniques. Dent Mater 2011;27:1045-1053.

34. Krejci I, Reich T, Lutz F, Albertoni M. [An in vitro test procedure for evaluating dental restoration systems. 1. A computer-controlled mastication simulator]. Schweiz Monatsschr Zahnmed 1990;100:953-960.

35. Wissenschaftliche Tabellen Geigy, Teilband Statistik. Basel; 1980.

36. Zhang Y, Lawn BR, Rekow ED, Thompson VP. Effect of sandblasting on the long-term performance of dental ceramics. J Biomed Mater Res. Part B, Appl Biomater 2004;71:381-386.

37. Karakoca S, Yilmaz H. Influence of surface treatments on surface roughness, phase transformation, and biaxial flexural strength of $\mathrm{Y}-\mathrm{TZP}$ ceramics. $\mathrm{J}$ Biomed Mater Res. Part B, Appl Biomater 2009;91:930-937.

38. Luthardt RG, Holzhuter M, Sandkuhl O, Herold V, Schnapp JD, Kuhlisch E, et al. Reliability and properties of ground Y-TZP-zirconia ceramics. J Dent Res 2002;81:487-491. 
39. Luthardt RG, Holzhuter MS, Rudolph H, Herold V, Walter MH. CAD/CAMmachining effects on Y-TZP zirconia. Dent Mater 2004;20:655-662.

40. Fischer J, Stawarzcyk B, Trottmann A, Hammerle $\mathrm{CH}$. Impact of thermal misfit on shear strength of veneering ceramic/zirconia composites. Dent Mater 2009;25:419-423.

41. Patil R, Subbarao E. Axial thermal expansion of $\mathrm{ZrO} 2$ and $\mathrm{HfO} 2$ in the range room temperature to $1400^{\circ} \mathrm{C}$. J Appl Crystallogr 1969;2:281-288.

42. Tholey MJ, Swain MV, Thiel N. Thermal gradients and residual stresses in veneered Y-TZP frameworks. Dent Mater 2011;27:1102-1110. 
Tables

TABLE I. Ceramic materials used and their composition, manufacturers and batch numbers.

TABLE II. Mean (SD) and 95\% confidence interval of the fracture load (N) and $95 \%$ confidence intervals for the difference test groups.

TABLE III. Weibull modulus $(\mathrm{m})$ and characteristic fracture load $\left(\sigma_{0}\right)$ with the corresponding $95 \%$ confidence intervals.

TABLE IV. Failure types with relative frequencies and $95 \%$ confidence interval for all tested groups and all failure types.

Figures

FIGURE 1. Mean initial fracture load $(\mathrm{N})$ with different conditioning methods for each veneering ceramic separately.

FIGURE 2. Mean fracture load $(\mathrm{N})$ after aging with different conditioning methods for each veneering ceramic separately.

FIGURE 3. SEM pictures of air-abraded Y-TZP surface: a) after air-abrasion using 50

$\mu \mathrm{m}$ alumina powder and b) after air-abrasion using $110 \mu \mathrm{m}$ alumina powder. 
Tables:

TABLE I. Ceramic materials used and their composition, manufacturers and batch numbers.

\begin{tabular}{|c|c|c|c|}
\hline & & Manufacturers & Batch-No. \\
\hline Framework & ZENO ZR $\left(\mathrm{ZrO}_{2}, \mathrm{HfO}_{2}, \mathrm{Y}_{2} \mathrm{O}_{3}, \mathrm{Al}_{2} \mathrm{O}_{3}\right.$, other oxide $)$ & $\begin{array}{l}\text { Wieland + Dental, } \\
\text { Pforzheim, } \\
\text { Germany }\end{array}$ & $\begin{array}{l}2008101 \\
0-21\end{array}$ \\
\hline \multirow[t]{3}{*}{$\begin{array}{l}\text { Veneering } \\
\text { ceramics }\end{array}$} & $\begin{array}{l}\text { Triceram }\left(\mathrm{SiO}_{2}, \mathrm{Al}_{2} \mathrm{O}_{3}, \mathrm{~K}_{2} \mathrm{O}, \mathrm{Na}_{2} \mathrm{O}, \mathrm{Li}_{2} \mathrm{O}, \mathrm{CaO}, \mathrm{BaO} \text {, }\right. \\
\left.\mathrm{MgO}, \mathrm{B}_{2} \mathrm{O}_{3}, \mathrm{~F} \text {, pigments }\right) \\
\text { Modelling Liquid }\end{array}$ & $\begin{array}{l}\text { Dentaurum, } \\
\text { Pforzheim, } \\
\text { Germany }\end{array}$ & $\begin{array}{l}023 \mathrm{~A} \\
017 \mathrm{~A}\end{array}$ \\
\hline & $\begin{array}{l}\text { Zirox }\left(\mathrm{SiO}_{2}, \mathrm{Al}_{2} \mathrm{O}_{3}, \mathrm{~K}_{2} \mathrm{O}, \mathrm{Na}_{2} \mathrm{O}, \mathrm{TiO}_{2}, \mathrm{ZrO}_{2}, \mathrm{CaO}, \mathrm{B}_{2} \mathrm{O}_{3}, \mathrm{~F},\right. \\
\mathrm{LiO}_{2} \text {, pigments) } \\
\text { Carving Liquid }\end{array}$ & $\begin{array}{l}\text { Wieland + Dental, } \\
\text { Pforzheim, } \\
\text { Germany }\end{array}$ & $\begin{array}{l}3 / 06 \\
30 / 06\end{array}$ \\
\hline & $\begin{array}{l}\text { VITA VM9 }\left(\mathrm{SiO}_{2}, \mathrm{Al}_{2} \mathrm{O}_{3}, \mathrm{~K}_{2} \mathrm{O}, \mathrm{Na}_{2} \mathrm{O}, \mathrm{TiO}_{2}, \mathrm{CeO}_{2}, \mathrm{ZrO}_{2} \text {, }\right. \\
\mathrm{CaO}, \mathrm{B}_{2} \mathrm{O}_{3}, \mathrm{BaO}, \mathrm{SnO}_{2}, \mathrm{P}_{2} \mathrm{O}_{5}, \mathrm{MgO}, \mathrm{FeO} \text {, pigments } \\
\text { Modelling Liquid }\end{array}$ & $\begin{array}{l}\text { Vita Zahnfabrik, } \\
\text { Bad Säckingen, } \\
\text { Germany }\end{array}$ & $\begin{array}{l}30250 \\
10780\end{array}$ \\
\hline
\end{tabular}


TABLE II. Mean (SD) and 95\% confidence interval of the fracture load (N) and

$95 \%$ confidence intervals for the difference test groups.

\begin{tabular}{|c|c|c|c|c|c|c|c|}
\hline & \multicolumn{2}{|l|}{ Triceram } & \multicolumn{2}{|l|}{ Zirox } & \multicolumn{2}{|l|}{ Vita VM9 } \\
\hline & & $50 \mu \mathrm{m}$ & $110 \mu \mathrm{m}$ & $50 \mu \mathrm{m}$ & $110 \mu \mathrm{m}$ & $50 \mu \mathrm{m}$ & $110 \mu \mathrm{m}$ \\
\hline \multicolumn{8}{|c|}{ Cementation surface } \\
\hline \multirow{2}{*}{$\begin{array}{l}\text { Non- } \\
\text { aged }\end{array}$} & Mean (SD) & $1179(240)^{A}$ & $1317(210)^{\mathrm{AB}}$ & $1141(178)^{A}$ & $1175(308)^{A}$ & $1278(135)^{A}$ & $1435(196)^{B}$ \\
\hline & $95 \% \mathrm{Cl}$ & $1026 ; 1332^{\text {ab }}$ & $1183 ; 1451^{\mathrm{C}}$ & $1028 ; 1255^{a}$ & $978 ; 1371^{a}$ & $1192 ; 1365^{D}$ & $1310 ; 1560^{b}$ \\
\hline \multirow[t]{2}{*}{ Aged } & Mean (SD) & $966(149)^{A}$ & $780(193)^{A}$ & $995(181)^{A}$ & $823(161)^{A}$ & $980(297)$ & $870(120)^{A}$ \\
\hline & $95 \% \mathrm{Cl}$ & $870 ; 1061^{b}$ & $657 ; 902^{a}$ & $879 ; 1111^{a}$ & $721 ; 926^{a}$ & $790 ; 1169^{a}$ & $793 ; 947^{a}$ \\
\hline \multicolumn{8}{|c|}{ Control groups } \\
\hline \multirow{2}{*}{$\begin{array}{l}\text { Non- } \\
\text { aged }\end{array}$} & Mean (SD) & \multicolumn{2}{|c|}{$1093(146)^{A}$} & \multicolumn{2}{|c|}{$999(144)^{A}$} & \multicolumn{2}{|c|}{$1089(174)^{A}$} \\
\hline & $95 \% \mathrm{Cl}$ & \multicolumn{2}{|c|}{$1000 ; 1186^{a, z}$} & \multicolumn{2}{|c|}{$907 ; 1091^{a, z}$} & \multicolumn{2}{|c|}{$978 ; 1200^{a, z}$} \\
\hline \multirow[t]{2}{*}{ Aged } & Mean (SD) & \multicolumn{2}{|c|}{$1076(159)^{A}$} & \multicolumn{2}{|c|}{$964(156)^{A}$} & \multicolumn{2}{|c|}{$1043(156)^{A}$} \\
\hline & $95 \% \mathrm{Cl}$ & \multicolumn{2}{|c|}{$974 ; 1178^{b, y}$} & \multicolumn{2}{|c|}{$865 ; 1063^{a, y}$} & \multicolumn{2}{|c|}{$908 ; 1179^{a, y}$} \\
\hline \multicolumn{8}{|c|}{ Veneering surface } \\
\hline \multirow{2}{*}{$\begin{array}{l}\text { Non- } \\
\text { aged }\end{array}$} & Mean (SD) & $1104(206)^{A}$ & $1317(247)^{A}$ & $1059(202)^{A}$ & $1123(166)^{\mathrm{A}}$ & $1150(216)^{A}$ & $1296(197)^{\mathrm{A}}$ \\
\hline & $95 \% \mathrm{Cl}$ & $973 ; 1236^{z y}$ & $1159 ; 1474^{y}$ & $930 ; 1188^{z}$ & $1017 ; 1229^{z}$ & $1013 ; 1287^{2 y}$ & $1170 ; 1421^{y}$ \\
\hline \multirow[t]{2}{*}{ Aged } & Mean (SD) & $848(189)^{A}$ & $754(219)^{A}$ & $966(124)^{A}$ & $637(116)^{A}$ & $936(209)^{A}$ & $794(209)^{A}$ \\
\hline & $95 \% \mathrm{Cl}$ & $727 ; 968^{z}$ & $614 ; 893^{z}$ & $887 ; 1046^{y}$ & $563 ; 712^{z}$ & $803 ; 1069^{z y}$ & $660 ; 927^{2}$ \\
\hline
\end{tabular}

The letters reflect the results from the one-way ANOVA. Superscript ${ }^{\mathrm{AB}}$ letters represent a significant post-hoc Scheffe test between the veneering ceramic among same conditioning and aging types. Superscript ${ }^{\mathrm{ab}}$ letters represent a significant post-hoc Scheffe test between cementation surface conditioning methods among same the veneering ceramic and aging types. Superscript ${ }^{\mathrm{y}}$ letters represent a significant post-hoc Scheffe test between veneering surface conditioning methods among same the veneering ceramic and aging types. 
TABLE III. Weibull modulus $(\mathrm{m})$ and characteristic fracture load $\left(\sigma_{0}\right)$ with the corresponding $95 \%$ confidence intervals.

\begin{tabular}{|c|c|c|c|c|c|c|c|}
\hline & & \multicolumn{2}{|l|}{ Triceram } & \multicolumn{2}{|l|}{ Zirox } & \multicolumn{2}{|l|}{ Vita VM9 } \\
\hline & & $50 \mu \mathrm{m}$ & $110 \mu \mathrm{m}$ & $50 \mu \mathrm{m}$ & $110 \mu \mathrm{m}$ & $50 \mu \mathrm{m}$ & $110 \mu \mathrm{m}$ \\
\hline \multicolumn{8}{|c|}{ Cementation surface } \\
\hline \multirow[t]{2}{*}{$\begin{array}{l}\text { Non- } \\
\text { aged }\end{array}$} & $\begin{array}{l}\text { Weibull modulus } \\
(95 \% \mathrm{Cl})\end{array}$ & $5.8(3.7 ; 9.2)$ & $7.3(4.7 ; 11.3)$ & $7.0(4.5 ; 10.8)$ & $4.5(2.8 ; 7.1)$ & $\begin{array}{l}10.4 \\
(6.7 ; 15.9)\end{array}$ & $9.4(6.0 ; 14.8)$ \\
\hline & $\begin{array}{l}\text { Characteristic } \\
\text { fracture load } \\
(95 \% \mathrm{Cl}) \mathrm{N}\end{array}$ & $\begin{array}{l}1274 \\
(1150 ; 1412)\end{array}$ & $\begin{array}{l}1403 \\
(1293 ; 1524)\end{array}$ & $\begin{array}{l}1218 \\
(1116 ; 1328)\end{array}$ & $\begin{array}{l}1289 \\
(1128 ; 1473)\end{array}$ & $\begin{array}{l}1338 \\
(1263 ; 1418)\end{array}$ & $\begin{array}{l}1514 \\
(1421 ; 1613)\end{array}$ \\
\hline \multirow[t]{2}{*}{ Aged } & $\begin{array}{l}\text { Weibull modulus } \\
(95 \% \mathrm{Cl})\end{array}$ & $7.7(4.9 ; 12.0)$ & $4.7(3.0 ; 7.3)$ & $6.0(4.0 ; 9.2)$ & $7.0(4.3 ; 11.1)$ & $3.8(2.4 ; 5.9)$ & $8.9(5.6 ; 14.0)$ \\
\hline & $\begin{array}{l}\text { Characteristic } \\
\text { fracture load } \\
(95 \% \mathrm{Cl}) \mathrm{N}\end{array}$ & $\begin{array}{l}1027 \\
(950 ; 1112)\end{array}$ & $852(749 ; 969)$ & $\begin{array}{l}1067 \\
(966 ; 1179)\end{array}$ & $882(810 ; 961)$ & $\begin{array}{l}1085 \\
(926 ; 1270)\end{array}$ & $920(860 ; 984)$ \\
\hline \multicolumn{8}{|c|}{ Control groups } \\
\hline \multirow[t]{2}{*}{$\begin{array}{l}\text { Non- } \\
\text { aged }\end{array}$} & $\begin{array}{l}\text { Weibull modulus } \\
(95 \% \mathrm{Cl})\end{array}$ & \multicolumn{2}{|c|}{$7.8(5.1 ; 11.8)$} & \multicolumn{2}{|c|}{$7.2(4.7 ; 10.9)$} & \multicolumn{2}{|c|}{$7.1(4.6 ; 11.1)$} \\
\hline & $\begin{array}{l}\text { Characteristic } \\
\text { fracture load } \\
(95 \% \mathrm{Cl}) \mathrm{N}\end{array}$ & \multicolumn{2}{|c|}{$1156(1070 ; 1250)$} & \multicolumn{2}{|c|}{$1062(976 ; 1155)$} & \multicolumn{2}{|c|}{$1162(1068 ; 1264)$} \\
\hline \multirow[t]{2}{*}{ Aged } & $\begin{array}{l}\text { Weibull modulus } \\
(95 \% \mathrm{Cl})\end{array}$ & \multicolumn{2}{|c|}{$6.4(4.3 ; 9.4)$} & \multicolumn{2}{|c|}{$7.4(4.7 ; 11.6)$} & \multicolumn{2}{|c|}{$5.8(3.7 ; 9.1)$} \\
\hline & $\begin{array}{l}\text { Characteristic } \\
\text { fracture load } \\
(95 \% \mathrm{Cl}) \mathrm{N}\end{array}$ & \multicolumn{2}{|c|}{$1145(1042 ; 1259)$} & \multicolumn{2}{|c|}{$1028(948 ; 1114)$} & \multicolumn{2}{|c|}{$1127(1016 ; 1)$} \\
\hline \multicolumn{8}{|c|}{ Veneering surface } \\
\hline \multirow[t]{2}{*}{$\begin{array}{l}\text { Non- } \\
\text { aged }\end{array}$} & $\begin{array}{l}\text { Weibull modulus } \\
(95 \% \mathrm{Cl})\end{array}$ & $6.6(4.2 ; 10.4)$ & $5.7(3.7 ; 8.6)$ & $6.0(3.8 ; 9.3)$ & $7.0(4.6 ; 10.4)$ & $6.6(4.1 ; 10.5)$ & $7.7(4.9 ; 12.1)$ \\
\hline & $\begin{array}{l}\text { Characteristic } \\
\text { fracture load } \\
(95 \% \mathrm{Cl}) \mathrm{N}\end{array}$ & $\begin{array}{l}1185 \\
(1083 ; 1298)\end{array}$ & $\begin{array}{l}1419 \\
(1275 ; 1579)\end{array}$ & $\begin{array}{l}1140 \\
(1031 ; 1261)\end{array}$ & $\begin{array}{l}1194 \\
(1095 ; 1302)\end{array}$ & $\begin{array}{l}1236 \\
(1129 ; 1353)\end{array}$ & $\begin{array}{l}1378 \\
(1275 ; 1489)\end{array}$ \\
\hline \multirow[t]{2}{*}{ Aged } & $\begin{array}{l}\text { Weibull modulus } \\
(95 \% \mathrm{Cl})\end{array}$ & $5.1(3.3 ; 7.8)$ & $4.2(2.6 ; 6.8)$ & $9.2(6.0 ; 14.2)$ & $7.2(4.4 ; 11.6)$ & $5.1(3.3 ; 7.8)$ & $5.2(3.1 ; 8.7)$ \\
\hline & $\begin{array}{l}\text { Characteristic } \\
\text { fracture load } \\
(95 \% \mathrm{Cl}) \mathrm{N}\end{array}$ & $\begin{array}{l}918 \\
(817 ; 1032)\end{array}$ & $833(722 ; 960)$ & $\begin{array}{l}1017 \\
(953 ; 1086)\end{array}$ & $683(628 ; 742)$ & $\begin{array}{l}1015 \\
(902 ; 1143)\end{array}$ & $867(775 ; 971)$ \\
\hline
\end{tabular}


TABLE IV. Failure types with relative frequencies and $95 \%$ confidence interval for all tested groups and all failure types.

\begin{tabular}{|c|c|c|c|c|c|c|c|}
\hline & & \multicolumn{6}{|c|}{ Failure types with relative frequency $(95 \% \mathrm{Cl})$} \\
\hline & & \multicolumn{2}{|l|}{ Triceram } & \multicolumn{2}{|l|}{ Zirox } & \multicolumn{2}{|l|}{ Vita VM9 } \\
\hline & & $\begin{array}{l}50 \mu m \\
(n=12)\end{array}$ & $\begin{array}{l}110 \mu m \\
(n=12)\end{array}$ & $\begin{array}{l}50 \mu m \\
(n=12)\end{array}$ & $\begin{array}{l}110 \mu \mathrm{m} \\
(\mathrm{n}=12)\end{array}$ & $\begin{array}{l}50 \mu m \\
(n=12)\end{array}$ & $\begin{array}{l}110 \mu m \\
(n=12)\end{array}$ \\
\hline \multicolumn{8}{|c|}{ Cementation surface } \\
\hline \multirow[t]{2}{*}{$\begin{array}{l}\text { Non- } \\
\text { aged }\end{array}$} & Total fracture & $\begin{array}{l}\mathrm{n}=6 \\
50 \quad(21.0 ; 79.0) \\
\%\end{array}$ & $\begin{array}{l}n=9 \\
75 \\
(42.8 ; 94.6) \%\end{array}$ & $\begin{array}{l}n=3 \\
25(5.4 ; 57.2) \%\end{array}$ & $\begin{array}{l}n=5 \\
42 \\
(15.1 ; 72.4) \%\end{array}$ & $\begin{array}{l}\mathrm{n}=7 \\
58.3 \\
(27.6 ; 84.9) \%\end{array}$ & $\begin{array}{l}n=10 \\
83.3 \\
(51.5 ; 98.0) \%\end{array}$ \\
\hline & $\begin{array}{l}\text { Framework } \\
\text { intakt, } \\
\text { chipping }\end{array}$ & $\begin{array}{l}n=6 \\
50(21.0 ; 79.0) \\
\%\end{array}$ & $\begin{array}{l}n=3 \\
25(5.4 ; 57.2) \%\end{array}$ & $\begin{array}{l}n=9 \\
75 \\
(42.8 ; 94.6) \%\end{array}$ & $\begin{array}{l}n=7 \\
58.3 \\
(27.6 ; 84.9) \%\end{array}$ & $\begin{array}{l}n=5 \\
42 \\
(15.1 ; 72.4) \%\end{array}$ & $\begin{array}{l}n=2 \\
16.7 \\
(2.0 ; 48.5) \%\end{array}$ \\
\hline \multirow[t]{2}{*}{ Aged } & Total fracture & $\begin{array}{l}\mathrm{n}=6 \\
50 \quad(21.0 ; 79.0) \\
\%\end{array}$ & $\begin{array}{l}n=8 \\
66.7 \\
(34.8 ; 90.1) \%\end{array}$ & $\begin{array}{l}\mathrm{n}=6 \\
50 \quad(21.0 ; 79.0) \\
\%\end{array}$ & $\begin{array}{l}n=9 \\
75 \\
(42.8 ; 94.6) \%\end{array}$ & $\begin{array}{l}n=7 \\
58.3 \\
(27.6 ; 84.9) \%\end{array}$ & $\begin{array}{l}n=7 \\
58.3 \\
(27.6 ; 84.9) \%\end{array}$ \\
\hline & $\begin{array}{l}\text { Framework } \\
\text { intakt, } \\
\text { chipping }\end{array}$ & $\begin{array}{l}n=6 \\
50 \quad(21.0 ; 79.0) \\
\%\end{array}$ & $\begin{array}{l}n=4 \\
33.3 \\
(9.9 ; 65.2) \%\end{array}$ & $\begin{array}{l}\mathrm{n}=6 \\
50 \quad(21.0 ; 79.0) \\
\%\end{array}$ & $\begin{array}{l}n=3 \\
25 \\
(5.4 ; 57.2) \%\end{array}$ & $\begin{array}{l}n=5 \\
42 \\
(15.1 ; 72.4) \%\end{array}$ & $\begin{array}{l}n=5 \\
42 \\
(15.1 ; 72.4) \%\end{array}$ \\
\hline \multicolumn{8}{|c|}{ Control groups } \\
\hline \multirow[t]{2}{*}{$\begin{array}{l}\text { Non- } \\
\text { aged }\end{array}$} & Total fracture & \multicolumn{2}{|c|}{$\begin{array}{c}n=2 \\
16.7(2.0 ; 48.5) \%\end{array}$} & \multicolumn{2}{|c|}{$\begin{array}{c}n=4 \\
33.3(9.9 ; 65.2) \%\end{array}$} & \multicolumn{2}{|c|}{$\begin{array}{c}\mathrm{n}=6 \\
50(21.0 ; 79.0) \%\end{array}$} \\
\hline & $\begin{array}{l}\text { Framework } \\
\text { intakt, } \\
\text { chipping }\end{array}$ & \multicolumn{2}{|c|}{$\begin{array}{c}n=10 \\
83.3(51.5 ; 98.0) \%\end{array}$} & \multicolumn{2}{|c|}{$\begin{array}{c}n=8 \\
66.7(34.8 ; 90.1) \%\end{array}$} & \multicolumn{2}{|c|}{$\begin{array}{c}\mathrm{n}=6 \\
50(21.0 ; 79.0) \%\end{array}$} \\
\hline \multirow[t]{2}{*}{ Aged } & Total fracture & \multicolumn{2}{|c|}{$\begin{array}{c}\mathrm{n}=7 \\
58.3(27.6 ; 84.9) \%\end{array}$} & \multicolumn{2}{|c|}{$\begin{array}{c}n=4 \\
33.3(9.9 ; 65.2) \%\end{array}$} & \multicolumn{2}{|c|}{$\begin{array}{c}\mathrm{n}=7 \\
58.3(27.6 ; 84.9) \%\end{array}$} \\
\hline & $\begin{array}{l}\text { Framework } \\
\text { intakt, } \\
\text { chipping }\end{array}$ & \multicolumn{2}{|c|}{$\begin{array}{c}n=5 \\
42(15.1 ; 72.4) \%\end{array}$} & \multicolumn{2}{|c|}{$\begin{array}{c}n=8 \\
66.7(34.8 ; 90.1) \%\end{array}$} & \multicolumn{2}{|c|}{$\begin{array}{c}n=5 \\
42(15.1 ; 72.4) \%\end{array}$} \\
\hline \multicolumn{8}{|c|}{ Veneering surface } \\
\hline \multirow[t]{2}{*}{$\begin{array}{l}\text { Non- } \\
\text { aged }\end{array}$} & Total fracture & $\begin{array}{l}n=5 \\
42 \\
(15.1 ; 72.4) \%\end{array}$ & $\begin{array}{l}n=8 \\
66.7 \\
(34.8 ; 90.1) \%\end{array}$ & $\begin{array}{l}n=3 \\
25(5.4 ; 57.2) \%\end{array}$ & $\begin{array}{l}n=4 \\
33.3 \\
(9.9 ; 65.2) \%\end{array}$ & $\begin{array}{l}n=8 \\
66.7 \\
(34.8 ; 90.1) \%\end{array}$ & $\begin{array}{l}n=8 \\
66.7 \\
(34.8 ; 90.1) \%\end{array}$ \\
\hline & $\begin{array}{l}\text { Framework } \\
\text { intakt, } \\
\text { chipping }\end{array}$ & $\begin{array}{l}n=7 \\
58.3 \\
(27.6 ; 84.9) \%\end{array}$ & $\begin{array}{l}n=4 \\
33.3 \\
(9.9 ; 65.2) \%\end{array}$ & $\begin{array}{l}n=9 \\
75 \\
(42.8 ; 94.6) \%\end{array}$ & $\begin{array}{l}n=8 \\
66.7 \\
(34.8 ; 90.1) \%\end{array}$ & $\begin{array}{l}n=4 \\
33.3 \\
(9.9 ; 65.2) \%\end{array}$ & $\begin{array}{l}n=4 \\
33.3 \\
(9.9 ; 65.2) \%\end{array}$ \\
\hline \multirow[t]{2}{*}{ Aged } & Total fracture & $\begin{array}{l}n=12 \\
100 \\
(73.5 ; 100) \%\end{array}$ & $\begin{array}{l}n=10 \\
83.3 \\
(51.5 ; 98.0) \%\end{array}$ & $\begin{array}{l}n=11 \\
91.7 \\
(61.5 ; 99.8) \%\end{array}$ & $\begin{array}{l}n=12 \\
100 \\
(73.5 ; 100) \%\end{array}$ & $\begin{array}{l}n=11 \\
91.7 \\
(61.5 ; 99.8) \%\end{array}$ & $\begin{array}{l}\mathrm{n}=11 \\
91.7 \\
(61.5 ; 99.8) \%\end{array}$ \\
\hline & $\begin{array}{l}\text { Framework } \\
\text { intakt, } \\
\text { chipping }\end{array}$ & $\begin{array}{l}n=0 \\
0(0 ; 26.5) \%\end{array}$ & $\begin{array}{l}n=2 \\
16.7 \\
(2.0 ; 48.5) \%\end{array}$ & $\begin{array}{l}n=1 \\
8.3 \\
(0.2 ; 38.5) \%\end{array}$ & $\begin{array}{l}n=0 \\
0(0 ; 26.5) \%\end{array}$ & $\begin{array}{l}n=1 \\
8.3 \\
(0.2 ; 38.5) \%\end{array}$ & $\begin{array}{l}n=1 \\
8.3 \\
(0.2 ; 38.5) \%\end{array}$ \\
\hline
\end{tabular}




\section{Figures:}

FIGURE 1. Mean initial fracture load $(\mathrm{N})$ with different conditioning methods for each veneering ceramic separately.

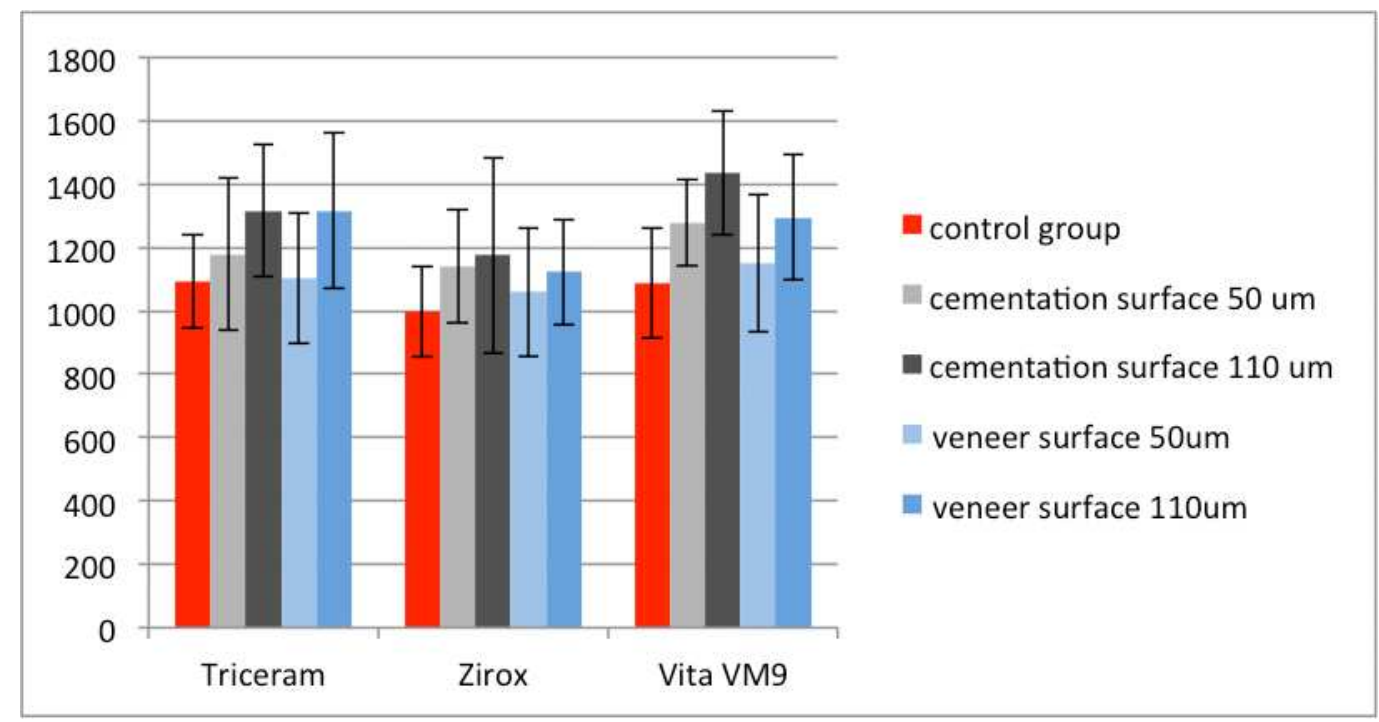


FIGURE 2. Mean fracture load (N) after aging with different conditioning methods for each veneering ceramic separately.

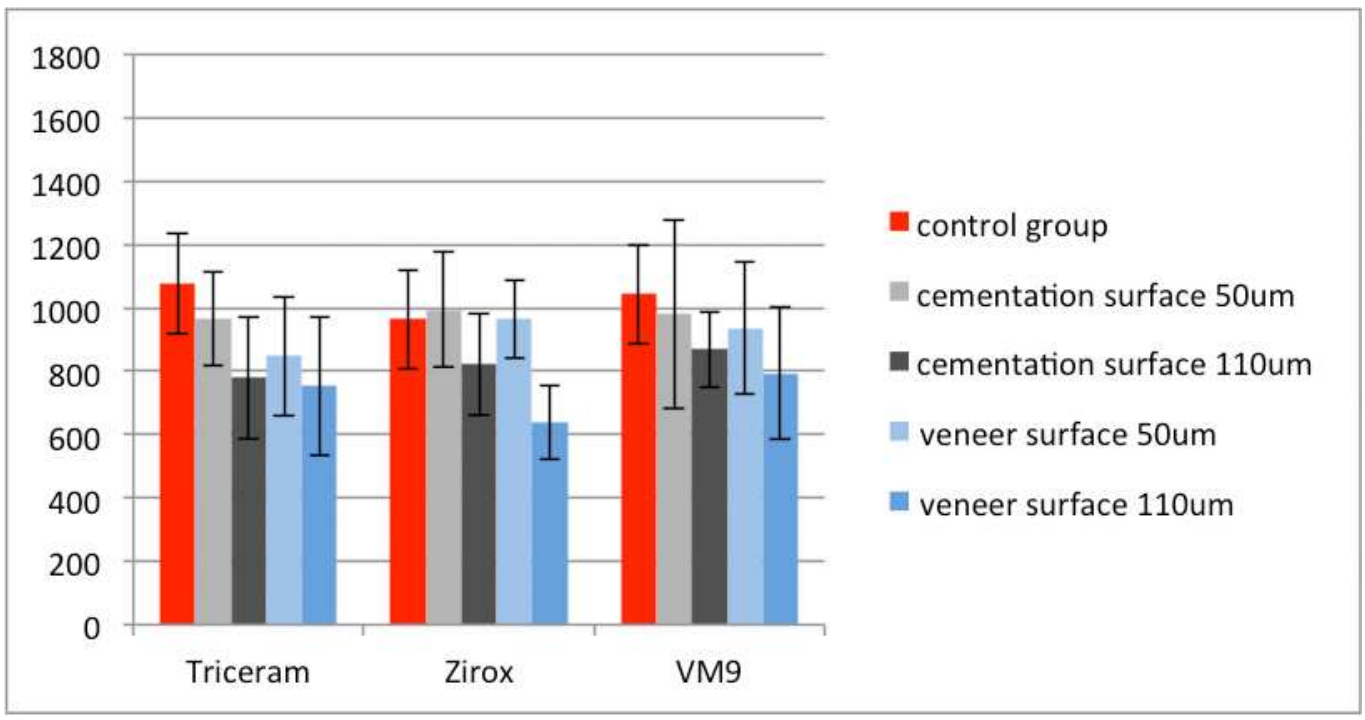


FIGURE 3. SEM pictures of air-abraded Y-TZP surface: a) after air-abrasion using 50 $\mu \mathrm{m}$ alumina powder and b) after air-abrasion using $110 \mu \mathrm{m}$ alumina powder.

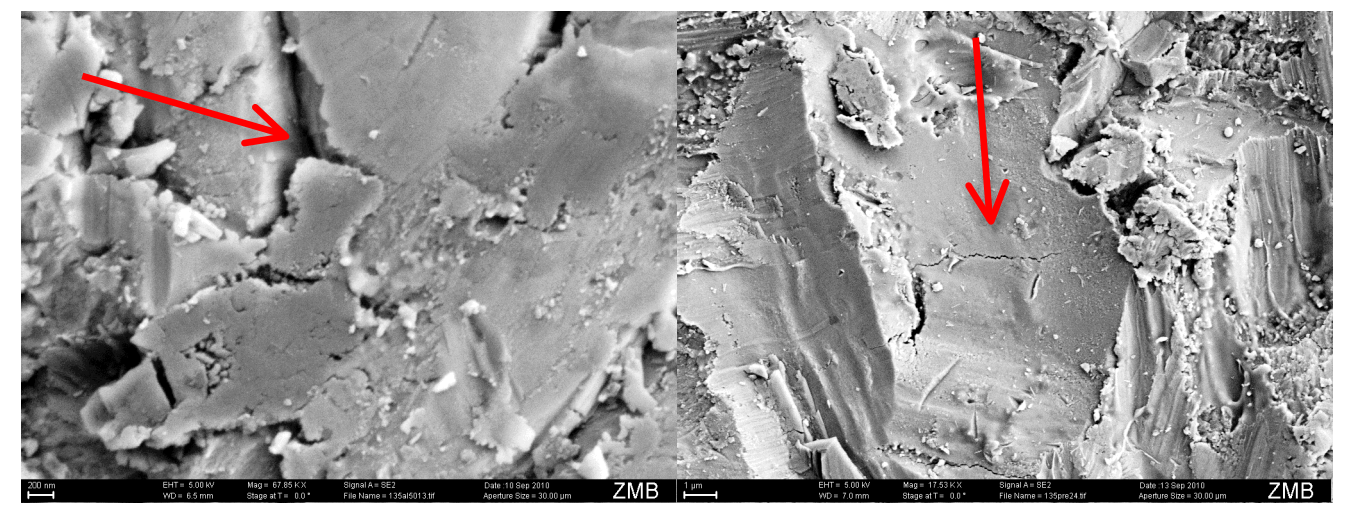

